\title{
The last Iberian gomphothere (Mammalia, Proboscidea): Anancus arvernensis mencalensis nov. ssp. from the earliest Pleistocene of the Guadix Basin (Granada, Spain)
}

\author{
Guiomar Garrido and Alfonso Arribas
}

\begin{abstract}
This work describes a new finding of Anancus arvernensis-a maxilla fragment that preserves M2 and M3-from the earliest Pleistocene (c.a. 2.5-2.4 Ma) at the Fonelas SCC-3 site (Cuenca de Guadix, Granada, Spain). This fossil is attributed to a new chronosubspecies based on the combination of anatomical features shown by M3: a primitive anatomical pattern plus derived features. The primitive features include the hexalophodont condition, a massive, rectangular distal outline, inconspicuous enamel folding, and indiscernible anancoidy. The derived features-tooth-valleys covered by cement and the small overall size of the tooth-are typical of the last representatives of the lineage. This mosaic of features allows a new chronosubspecies to be proposed: Anancus arvernensis mencalensis nov. ssp. This would be the youngest representative of the genus Anancus known for the Iberian Peninsula (MNQ 17a), and represents an intermediate evolutionary stage between Anancus arvernensis arvernensis and Anancus arvernensis chilhiacensis, the last known representative of the European lineage. $A$. arvernensis mencalensis therefore forms part of a temporal cline in the configuration of M3 over the Plio-Pleistocene transition. These anatomical changes could have occurred as a response to the aridification that began around $2.5 \mathrm{Ma}$, which led to changes in the composition of plant communities.
\end{abstract}

Guiomar Garrido. Estación Paleontológica Valle del Río Fardes, Instituto Geológico y Minero de España (IGME), Ríos Rosas 23, 28003 Madrid, Spain g.garrido@igme.es

Alfonso Arribas. Estación Paleontológica Valle del Río Fardes, Instituto Geológico y Minero de España (IGME), Ríos Rosas 23, 28003 Madrid, Spain a.arribas@igme.es

KEYWORDS: Proboscidea; Anancus; new chronosubspecies; Early Pleistocene; Guadix Basin; Iberian Peninsula 


\section{INTRODUCTION}

Anancine gomphotheres (Anancus Aymard [in Dorlhac, 1855]) originated in Eurasia. They probably derived from Tetralophodon Falconer, 1857, displacing it during the late Miocene to become distributed throughout the Old World until the early Pleistocene (ca. -2.3 Ma). The type species is Anancus arvernensis (Croizet and Jobert, 1828), the only one presently accepted to have lived in the west of the European continent. A. arvernensis was fairly common in European ecosystems during Pliocene.

In certain European Villafranchian deposits, Anancus fossils are found along with other species of Proboscidea. For example, they are associated with Mammut borsoni (Hays, 1834) in Perrier-Etouaires and Vialette (MNQ 16a), and with Mammuthus meridionalis (Nesti, 1825) in Saint Vallier (MNQ 17a; Viret, 1954; Guérin, 2004), Costa San Giacomo (MNQ 17b; Palombo and Valli, 2003) and Chilhac (MNQ 17b; Boeuf, 1992). Mammuthus Brookes, 1828 appeared in Western Europe around 3 m.y.a. and for the moment no lberian site has yet provided any evidence of coexistence between Anancus and Mammuthus. Anancus eventually become extinct, while Mammuthus meridionalis expanded with great success across the continent. The environment of the time seemed to have been optimal for this new lineage, for which chronological variation across Eurasia has been described (Lister et al., 2005).

In the Iberian Peninsula, fossils of $A$. arvernensis have been recovered from many sites (see Mazo and van der Made, 2012) between zones MNQ 12 (Concud, Teruel; Alcalá, 1994) and MNQ 16-17 (Villarroya, La Rioja; Villalta, 1952). The most important is the site of Las Higueruelas (Ciudad Real, MNQ 16; Mazo et al., 1980), where abundant fossil remains of this species have been recovered.

In the Guadix Basin, Anancus was previously cited for Huélago-1 (MNQ 17; Alonso et al., 2002), where it may have coexisted with Mammuthus. However, this cannot be verified due to the taphonomic reworking of the Anancus fossil tooth fragments (A. Arribas, personal observation).

Anancus appears in Africa near the end of the Miocene, coincident with the first appearance of elephants on that continent. It persisted there well into the Early Pleistocene.

To date, only $A$. arvernensis is fully recognized in the European context. It existed for several million years and showed wide variation. As a consequence distinct subspecies are recognized. In contrast, for the same chronological interval, different species of the genus Anancus are accepted, both in Africa and Asia. Currently, five African species of Anancus have been identified (Sanders, 2011): Anancus kenyensis (Maclnnes, 1942), Anancus ultimus Sanders, 2011, Anancus capensis Sanders, 2007, Anancus petrocchii Coppens, 1965, and Anancus osiris Arambourg, 1945. Five Asian species of Anancus are also recognized: Anancus sinensis (Hopwood, 1935) and Anancus cuneatus (Teilhard de Chardin and Trassaert, 1937) from China, two species based on materials recovered in the foothills of the Siwaliks in India, i.e., Anancus sivalensis (Cautley, 1836) and Anancus perimensis (Falconer and Cautley, 1846), and Anancus kazachstanensis (Aubekerova, 1974) from Kazakhstan.

\section{GEOLOGICAL AND CHRONOLOGICAL SETTING}

The paleontological site of Fonelas Solana del Cortijo Conejo 3 (Fonelas SCC-3) was discovered during the systematic surveying campaign of 2006 , undertaken as part of the Fonelas Project. The site is located in the Guadix Basin (Granada, Spain) near the town of Fonelas (UTM coordinates 482407, 4141795) (Figure 1.1-1.3).

Fonelas SCC-3 is part of Unit V (Early Pleistocene) of the basin fill (Pla-Pueyo et al., 2011), and the fossilized remains of Proboscidea found in it fall into a layer of conglomerates that form part of a high-energy fluvial channel facies within the Axial System (Viseras, 1991). Magnetostratigraphic studies of this stratrigraphic column have shown a good correlation with GTS2004 (Lourens et al., 2004), locating Fonelas SCC-3 to the base of a reverse magnetozone (Matuyama Chron) where two successive subchrons with normal polarity are recognized (Reunion C2r.1n and Olduvai C2n). Fonelas SCC-1 (MNQ 18; Guérin, 1990; Mein, 1990 ) is located between these subchrons, near the bottom of the Olduvai magnetozone. Therefore, Fonelas SCC-3 can be precisely assigned to the early Matuyama (pre-Reunion; Figure 2), i.e., it is 2.4-2.5 million years old and therefore within the MNQ 17a zone (according to Nomade et al., in press).

\section{MATERIAL AND METHODS}

The fossil described in this work was collected during the above-mentioned 2006 survey and is provisionally held at the headquarters of the Geological Survey of Spain in Madrid's Museo Geom- 


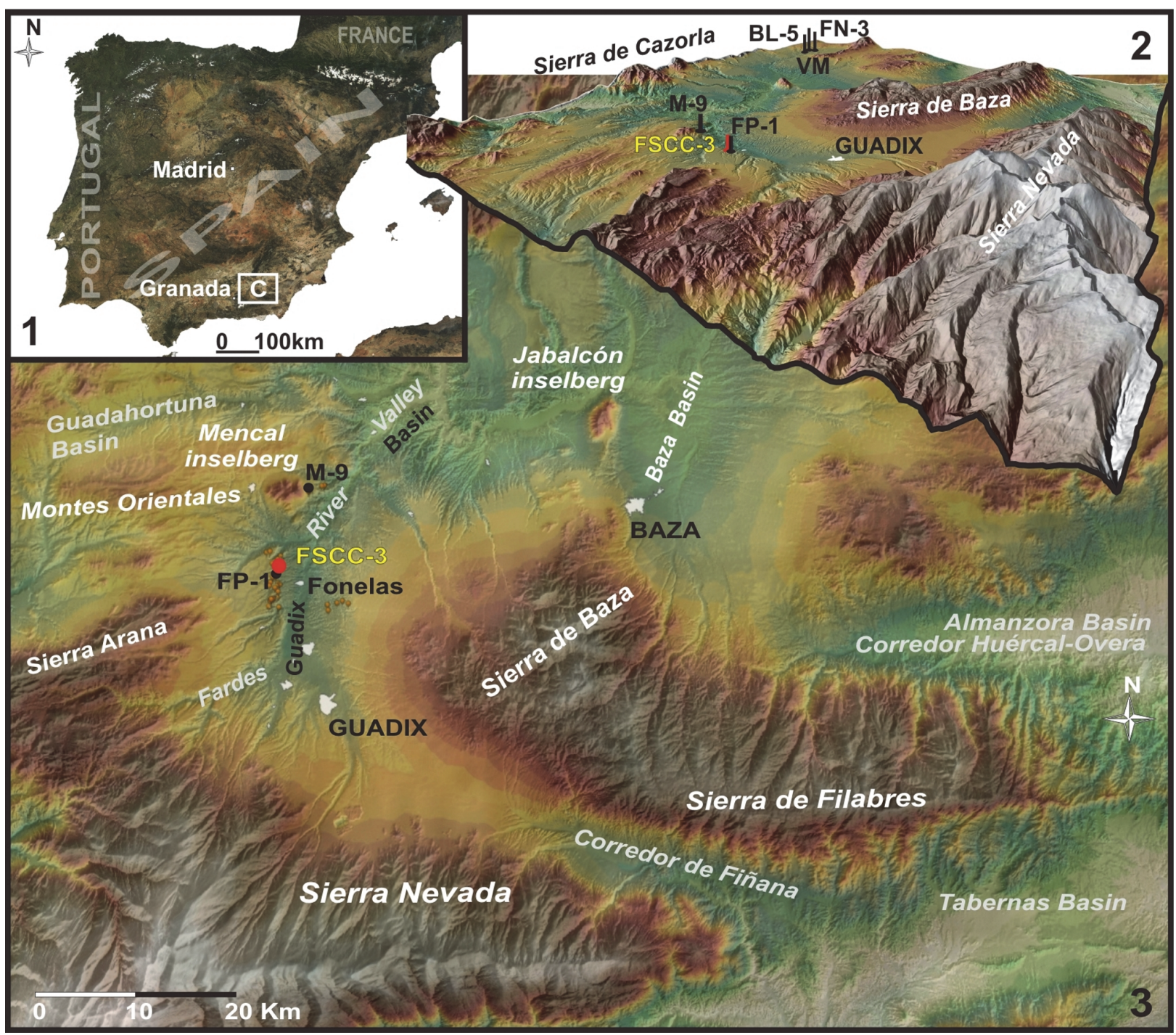

FIGURE 1. Geographical and geological setting of the Fonelas SSC-3 site. 1, location of the Guadix and Baza Basins in the southeastern Iberian Peninsula; 2, digital elevation model (DEM) (3D) of the Guadix and Baza Basins, and the high ground surrounding them. The position of Fonelas SCC-3 is indicated along with other important Early Pleistocene sites in the Guadix area (FP-1: Fonelas P-1; M-9: Mencal-9) and the three most important in the Baza area (VM: Venta Micena; BL-5: Barranco León-5; FN-3: Fuente Nueva-3); 3, DEM of the Guadix and Baza Basins showing their Early Pleistocene fossil sites (those listed above along with others, as yet undescribed in the literature, found during the Fonelas Project), plus the area's Paleozoic and Mesozoic ridges, corridors and associated Neogene basins. The current landscape model for the Fardes River Valley includes large expanses of badlands that increase the number outcrops of fossiliferous units and paleontological sites.

inero. The nomenclature and methods used in the anatomical description of the molar cusps were those proposed by Tassy (1986) (modified and simplified for the upper teeth). Measurements were taken using a Mitutoyo calliper (precision 0.01 $\mathrm{mm})$.

\section{Abbreviations}

$\mathbf{H}$, crown height; L, length; $\mathbf{M}$, upper molar; $\mathbf{m}$, lower molar; Ma, mega-annum; me, mesoconule;
MGM, Museo Geominero, Madrid, Spain; MN, Mammal Neogene Zone; MNCN, Museo Nacional de Ciencias Naturales, Madrid, Spain; MNQ, Mammal Neogene Quaternary Zone; m.y.a., million years ago; pr, pretrite principal tubercle; po, postrite principal tubercle; pacc, pretrite anterior central conule; ppcc, pretrite posterior central conule; popcc, postrite posterior central conule; prm, pretrite mesoconule; pom, postrite mesoconule; ac, anterior cingulum; pc, posterior cingulum; W, 

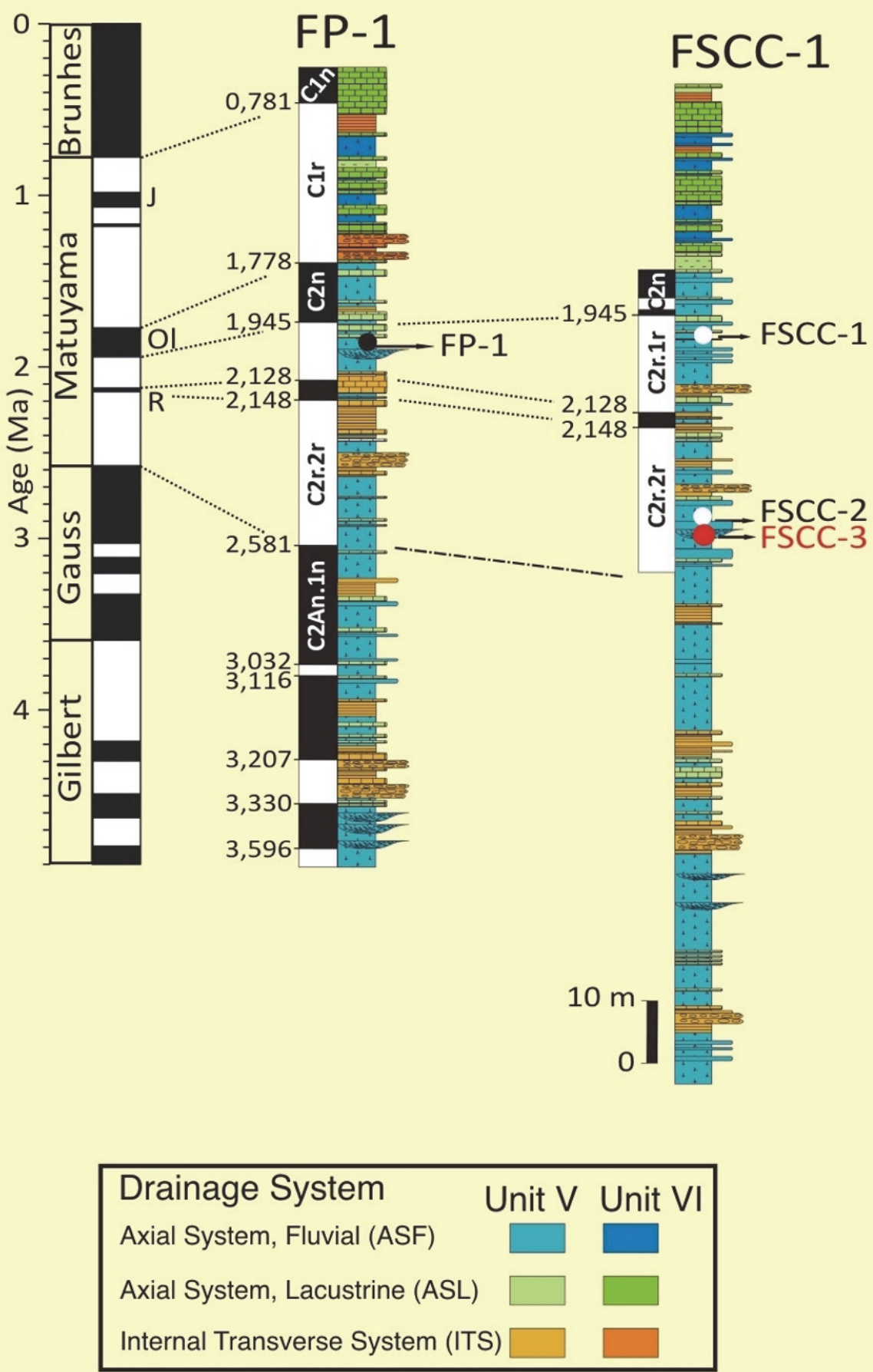

Correlation lines with GTS2004

(Lourens et al., 2004)

FIGURE 2. Stratigraphic profiles for Fonelas SCC-1 (which contain FSCC-3) and Fonelas P-1. Magnetostratigraphic information for each is provided (modified after Arribas et al., 2009; Pla-Pueyo et al., 2011). FSCC-3 is located at the lower part of the reverse Chron C2r.2r; its age is 2.4-2.5 Ma (Pla-Pueyo et al. 2011). 
width; WI, width index (maximum width $\times 100$ / length).

\section{SYSTEMATIC PALEONTOLOGY}

Order PROBOSCIDEA Illiger, 1811

Superfamily ELEPHANTOIDEA Gray, 1821

Family GOMPHOTHERIIDAE Hay, 1922

Subfamily ANANCINAE Hay, 1922

Genus ANANCUS Aymard (in Dorlhac, 1855)

Type species. Anancus arvernensis (Croizet and Jobert, 1828)

Genus diagnosis. Gomphotheriid with a high, short skull. Elevated dome. Enlarged tympanic bulla. Short mandible without tusks. Straight upper tusks without enamel. Loss of premolars. Tetralophodont intermediate molars (occasionally pentalophodont M2). Pretrite posterior central conule reduced in upper molars. Reduction of the pretrite anterior central conule on the lower molars and fusion with the mesoconelet. Alternation of the pretrite and postrite half-loph(id)s (anancoidy) allows the establishment of an alternative contact of successive loph(id)s, especially for the lower intermediates and $\mathrm{m} 3$. The upper third molar has five or six lophs and shows a trend towards simplification. Cementum is normally absent, although it is present in later taxa (Tassy, 1986 [modified]; Hautier et al., 2009).

\section{Anancus arvernensis mencalensis nov. ssp.} Figures 3-5

\section{http://zoobank.org/B3BAE8B4-1E82-448A-893A-} 4C814F7A1B8B

Derivatio nominis: From Cerro Mencal, a Jurassic inselberg rising $1447 \mathrm{~m}$ above sea level, representing a paleogeographic high in the northern part of the Guadix Basin (Figure 1.3). This high is a geological and historical landmark for this area. Mencal comes from the Arabic for cemetery or transit, probably related to the presence of burial sites with traces of prehistoric dolmens, and to caves occupied during Paleolithic times.

Holotype: Right maxilla fragment with $\mathrm{M} 2$ and $\mathrm{M} 3$ (FSCC-3-001; Figure 3). Held at the Museo Geominero.

Type locality: Fonelas SCC-3 (Guadix Basin, Granada, Spain). Early Pleistocene (c.a. 2.5-2.4 m.y.a.; Pla-Pueyo et al., 2011).

Occurrence: Fonelas SCC-3 (Guadix Basin, Granada, Spain).

Diagnosis: Anancus with tetralophodont intermediate upper molars. The upper third molar shows a unique combination of primitive and derived features. Among the former are a simple M3 crown with six lophs, inconspicuous enamel folding, indiscernible anancoidy, a widened distal area forming a subrectangular outline, and an absent basal cingulum. The derived features of this tooth include cementum deposits in the valleys between the cusps and an overall small size, intermediate between Anancus arvernensis arvernensis and Anancus arvernensis chilhiacensis.

Measurements: See Table 1.

\section{Description}

The Anancus material recovered at Fonelas SCC-3 consists of a fragment of hemimaxilla in which $\mathrm{M} 2$ and $\mathrm{M} 3$ are perfectly preserved in their alveoli (Figure 3). These teeth show bunodont morphology and narrow valleys between the lophs. The preserved maxillary bone fragment hardly allows for its anatomy to be examined, although it is possible to appreciate a palatine foramen that opens beyond the mesial limit of the third molar. The specimen was not considerably transported or rolled before final deposition and burial, as indicated by the absence of any abrasion signs on its surface.

M2 is a tetralophodont tooth, with moderately worn structures, especially in the mesial region (Figures 3.2, 4), in which thick $(6-8 \mathrm{~mm})$ smoothly folded enamel is visible. Despite the wear, an anterior cingulum with a straight mesial edge is clearly seen. The cingulum has become fused to the principal tubercles due to wear. However, a mesio-lingual low conule appears separate from the first pretrite principal tubercle (pr1). The outline of the mesio-distally flattened, postrite posterior central conule (popcc1) can also be distinguished. The second and third lophs show a pretrite anterior central conule (pacc2 and pacc3) fused to the pretrite principal tubercle (pr2 and pr3), and a mesoconule (me2 and me3) fused to the postrite principal tubercle (po2 and po3). The fourth loph shows the same structure as the previous two, although there is no mesoconule joined to the postrite principal tubercle. Finally, a cingulum in the central region of the distal part of the tooth is subdivided into three lobes, revealing the original existence of a large distal conule shifted to the lingual region, and two minor conules in the distal area of the postrite principal tubercle of the fourth loph.

M3 is a hexalophodont tooth, with lophs slightly inclined towards the mesial region (Figure 3.1). There is no visible cingulum in the basal region (neither labial nor lingual). The reduced wear shown by this tooth allowed a detailed examination of its structures. The lophs are formed by 

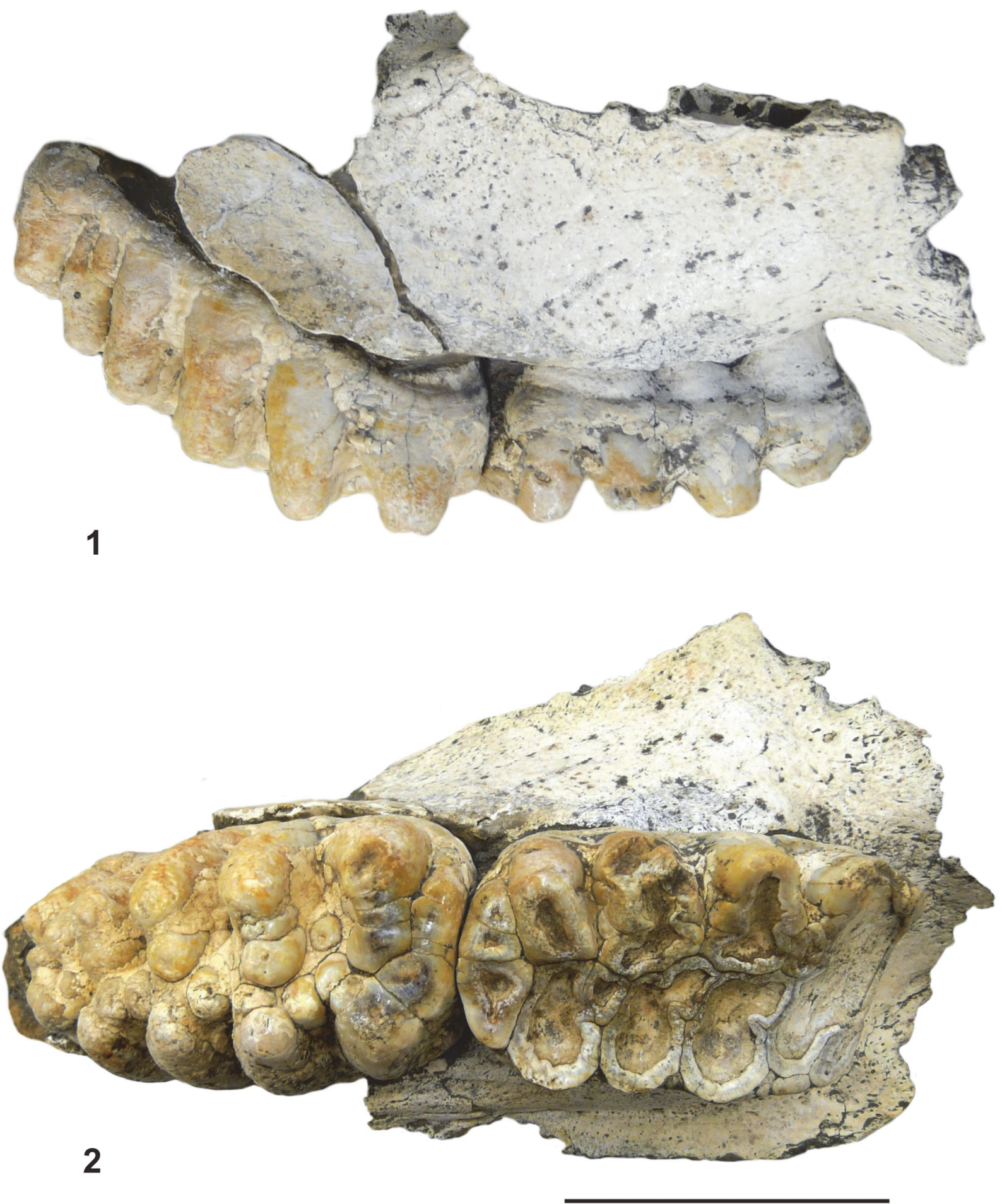

FIGURE 3. Fragment of the right maxilla of Anancus arvernensis mencalensis nov. ssp. (Fonelas SCC-3-001, holotype). 1, labial view; 2, occlusal view. Scale bar equals $10 \mathrm{~cm}$. 


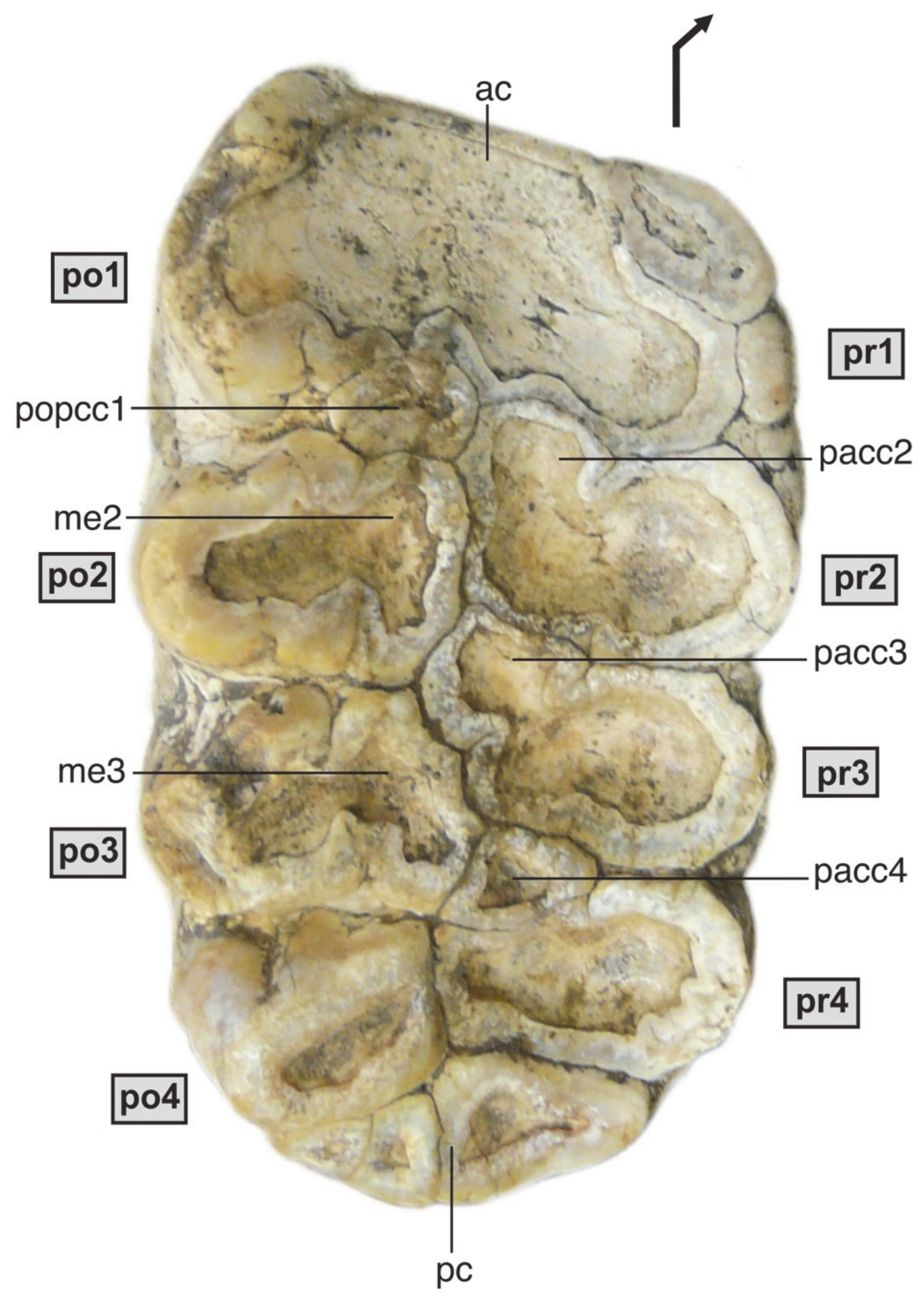

FIGURE 4. Occlusal view of the right M2 of Anancus arvernensis mencalensis nov. ssp. (Fonelas SCC-3-001, holotype) showing the abbreviations employed in the description of the dental structures. Scale bar equals $5 \mathrm{~cm}$. 


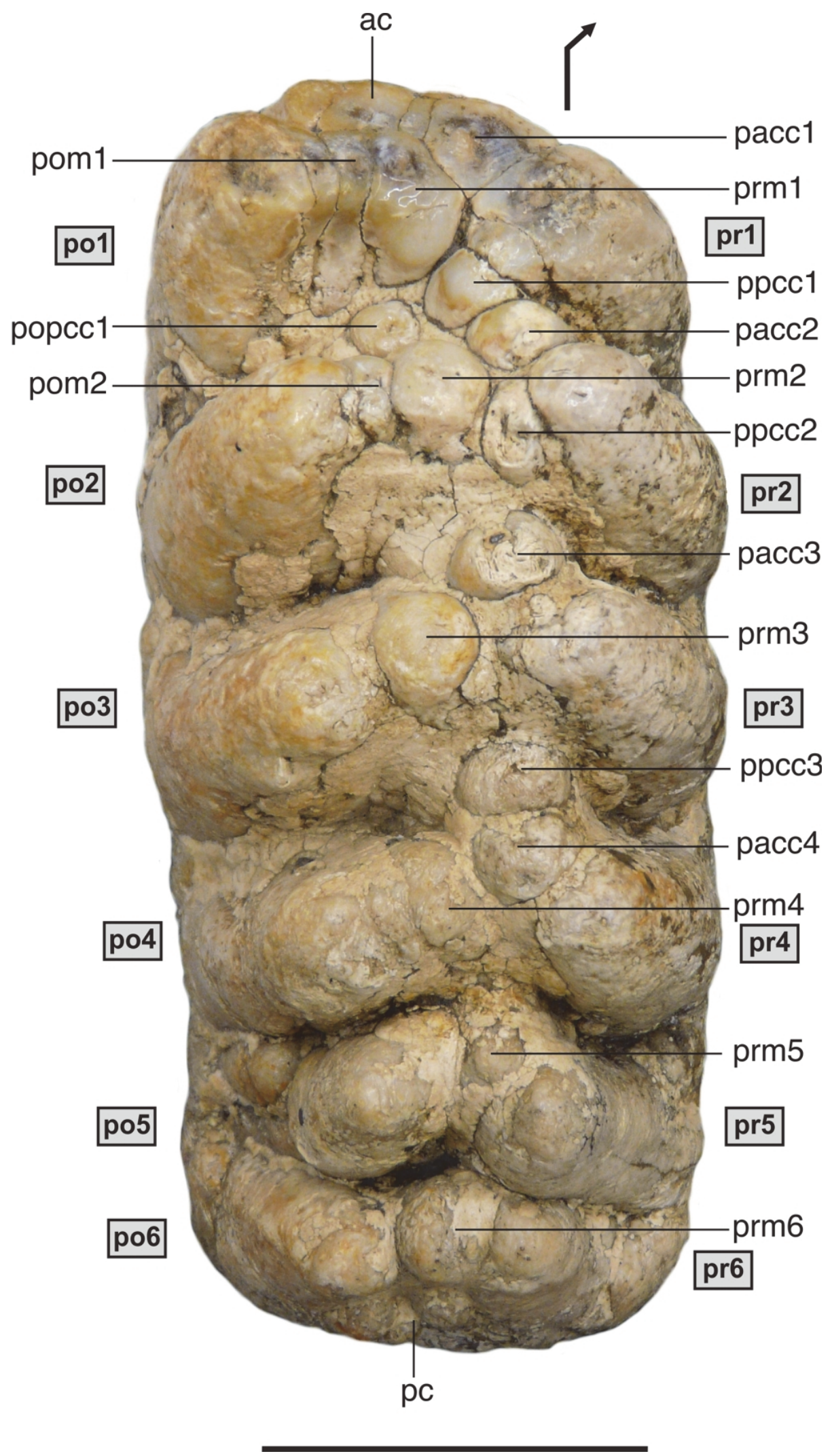

FIGURE 5. Occlusal view of the right M3 of Anancus arvernensis mencalensis nov. ssp. (Fonelas SCC-3-001, holotype) showing the abbreviations employed in the description of the dental structures. Scale bar equals $5 \mathrm{~cm}$. 
TABLE 1. Measurements of the teeth and their features (in $\mathrm{mm}$ ) from the maxilla fragment FSCC-3-001 (holotype) classified as Anancus arvernensis mencalensis nov ssp.

\begin{tabular}{|ccccccccccc|}
\hline & L & W 1 & W2 & W3 & W4 & W5 & W6 & WI & H \\
\hline M2 & 120.18 & 70.43 & 73.15 & 69.11 & 66.38 & 45.26 & - & 60.87 & - \\
\hline M3 & 166 & 69.61 & 74.05 & 74.06 & 70.37 & 68.67 & 64.84 & 44.61 & 64.7 \\
\hline
\end{tabular}

pairs of thick conical cusps known as principal tubercles, the height and overall size of which is reduced towards the distal region. No anancoid pattern among the pretrite and postrite principal tubercles is seen (Figure 5). The principal tubercles of one loph and those of the next are separated by deep valleys covered by cement aggregates. Between the principal tubercles of each loph lie a number of intermediate cusps that disappear towards the distal region of the tooth except the central conule, which is observed in all lophs (and is more individualized in the three mesial lophs). The tooth therefore shows a complex morphology in its mesial region that becomes simpler towards its distal part. Mesially, there is a well-developed anterior cingulum (ac), slightly shifted to the mesio-labial region and connected to the pretrite anterior central conule of the first loph (pacc1).

Between the pretrite (pr1) and postrite (po1) principal tubercles of the first loph lies a mesoconule subdivided into two completely fused conules (prm1 and pom1). In the valley that separates the first and second lophs there is a low pop$\mathrm{cc1}$, the top of which emerges from a large cement aggregate. In the central area of the second loph there is a large pretrite mesoconule (prm2), high enough to almost reach the principal tubercles. A very compressed cusp is seen between this and the postrite principal tubercle (po2), forming the postrite mesoconule (pom2). The third pretrite principal tubercle (pr3) appears with a well-developed and completely individualized pretrite anterior central conule (pacc3) that almost reaches the height of the third pretrite principal tubercle. A lower pretrite posterior central conule (ppcc3) reaches the height of the fourth pretrite principal tubercle (pr4). Thick cement aggregates appear among these elements that prevent the cusp bases from being seen; only the latter's apical region outcrops. The central area shows a single large mesoconule (prm3) slightly shifted towards the postrite principal tubercle (po3). In height it reaches the principal tubercles of the third loph. The fourth loph is substantially simpler than the previous ones, with a pretrite anterior central conule (pacc4) fused to the mesio-labial region of the pretrite principal tubercle (pr4), the cusps of which reach the same height (which equals that of ppcc3). The mesoconule (prm4) is completely fused to the postrite principal tubercle (po4); both reach the same height, which makes differentiation difficult.

The fifth loph consists of the two principal tubercles which are substantially lower in height than the previous ones, and a pretrite mesoconule (prm5) attached to pr5. In the mesio-labial area of po5 there is a small conical cusp occupying the labial valley between po4 and po5. The degree of development and differentiation of the M3 distal cusps, including the entoflexus behind the fifth loph, suggests they should be understood as an independent sixth loph and not part of the posterior cingulum. Curiously, this potential sixth loph (including pr6 and po6) does not emerge directly from the labial and lingual sides of the tooth, but from irregular platforms with a rectangular outline. In this region, the cement is less abundant, which allows examination of the deep valley between the components of the fifth and sixth lophs. Finally, in the distal region of the tooth, three basal thickenings form the outline of the posterior cingulum.

\section{COMPARISON}

The Fonelas SCC-3 hemimaxilla can be attributed to Anancus according to the anatomical features of the upper molars: bunodont morphology, a tetralophodont M2 and hexalophodont M3 with pretrite central conules (pacc and ppcc) (these are more developed than the postrite conules), and distal lophs with a reduced pretrite posterior central conule. At first glance, the most striking feature of the specimen is the absence of anancoidy in M3, a feature quite evident in almost all upper third molars of Anancus arvernensis. The absence of a basal cingulum also contrasts with other studied M3 specimens of $A$. arvernensis. A description of the Anancus species recognized for Old World paleontological sites is provided below so that comparisons can be made of the main anatomical dental features differentiating them from Fonelas SCC-3 specimen (see Tables 2 and 3 ): 
TABLE 2. Comparison of M3 from Fonelas SCC-3-001 and other specimens of Anancus arvernensis from Europe.

\begin{tabular}{|lccccc|}
\hline \multicolumn{1}{|c}{ Fossil Site } & Anancoidy & No. lophs in M3 & Cement & Age & Reference \\
\hline Fonelas SCC-3 & absent & 6 & present & $2.5-2.4 \mathrm{Ma}$ & This work \\
\hline Dorkovo & pronounced & $5-6$ & absent & $4.5 \mathrm{Ma}$ & Metz-Muller, 1995 \\
\hline Baza-1 & pronounced & 5 & absent & $\sim 4 \mathrm{Ma}$ & Ros, 2010 \\
\hline Las Higueruelas & pronounced & 5 & absent & $3.3 \mathrm{Ma}$ & Own data \\
\hline Hajnáčka & pronounced & 5 & traces & Villafranchian & Lupták, 1997 \\
\hline Chilhac & weak & 5 & present & $2.3-2.2 \mathrm{Ma}$ & Boeuf, 1992 \\
\hline
\end{tabular}

TABLE 3. Comparison of dental features in Fonelas SCC-3-001 and other European and African anancine gomphotheres.

\begin{tabular}{|c|c|c|c|c|c|c|}
\hline Species & $\begin{array}{l}\text { Anancoidy in } \\
\text { upper molars }\end{array}$ & $\begin{array}{c}\text { No. } \\
\text { lophs in } \\
\text { M2 }\end{array}$ & $\begin{array}{l}\text { No. lophs in } \\
\text { M3 }\end{array}$ & Enamel folding & Age & Reference \\
\hline $\begin{array}{l}\text { A. arvernensis } \\
\text { mencalensis }\end{array}$ & weak & 4 & 6 & none-coarse & Early Pleistocene & This work \\
\hline $\begin{array}{l}\text { A. arvernensis } \\
\text { turoliensis }\end{array}$ & weak & 4 & $5-6$ & none & Late Miocene & Own data \\
\hline $\begin{array}{l}\text { A. arvernensis } \\
\text { arvernensis }\end{array}$ & pronounced & $4-5$ & $5-6$ & coarse-moderate & Pliocene & Own data \\
\hline $\begin{array}{l}\text { A. arvernensis } \\
\text { falconeri }\end{array}$ & pronounced & 4 & 5 & coarse & Early Pleistocene & Guérin, 2004 \\
\hline $\begin{array}{l}\text { A. arvernensis } \\
\text { chilhiacensis }\end{array}$ & weak & 4 & 5 & coarse & Early Pleistocene & Boeuf, 1992 \\
\hline A. kenyensis & weak & 4 & $5-6$ & none-coarse & $\begin{array}{l}\text { Late Miocene-Early } \\
\text { Pliocene }\end{array}$ & $\begin{array}{l}\text { Hautier et al., } 2009 \\
\text { Sanders et al., } 2010\end{array}$ \\
\hline A. petrocchii & weak & 5 & unknown & unknown & Late Miocene & $\begin{array}{c}\text { Sanders, } 2011 \\
\text { Sanders, } 2007,2008\end{array}$ \\
\hline A. capensis & pronounced & 4 & $6-7$ & moderate-strong & $\begin{array}{c}\text { Late Miocene or Early } \\
\text { Pliocene }\end{array}$ & Sanders, 2007 \\
\hline A. ultimus & $\begin{array}{l}\text { moderate- } \\
\text { pronounced }\end{array}$ & 5 & $6-7$ & moderate-strong & Early-mid Pliocene & Sanders, 2011 \\
\hline A. osiris & weak & 4 & 6 & none-coarse & $\begin{array}{l}\text { Late Pliocene-Early } \\
\text { Pleistocene }\end{array}$ & Arambourg, 1945 \\
\hline
\end{tabular}

\section{Anancus in Western Europe}

Anancus arvernensis is, for now, the only widely accepted species of this genus for Western Europe. This Late Miocene-Early Pleistocene gomphothere had tetralophodont intermediate molars and upper third molars with five or six lophs. The enamel folding is coarse to fine, and the molar crown simple or complex and usually shows clear anancoidy (especially so in $\mathrm{m} 3$ ). This taxon includes several recognized subspecies:

Anancus arvernensis turoliensis Gaziry, 1997. The most primitive form of the species and typical of Turolian sites such as Dorn-Dürkheim 1 (MN11MN12) where it was first described. According to Metz-Muller (2000), this material should be classi- fied as Tetralophodon. This taxon is probably also present in Iberian sites such as Alfacar (Bergounioux and Crouzel, 1958). This subspecies has massive third upper molars that show weak (nearly absent) anancoidy.

Anancus arvernensis arvernensis (Croizet and Jobert, 1828). The most typical and abundant form of the genus during the European Pliocene. The type series is found in the Pliocene of Perrier-lesEtouaires (MN16). The upper third molars are normally pentalophodont, in which anancoidy is clearly visible. The distal part of this tooth narrows and there is always a well-developed basal cingulum.

Anancus arvernensis falconeri Osborn, 1926. This subspecies is based on fossils from the Late Pliocene of Red Crag (England). It has also been 
cited for the Late Pliocene French site of Saint Vallier (Guérin, 2004), and is considered typical of the Middle Villafranchian and of the lowermost Late Villafranchian. It has pentalophodont upper third molars, with anterior principal tubercles strongly inclined in the forward direction. Anancoidy is conspicuous. Narrow valleys between the lophs contain cement deposits.

Anancus arvernensis chilhiacensis Boeuf, 1992. This subspecies is based on specimens from the Early Pleistocene deposits of Chilhac (MNQ17b), recently estimated at about 2.2 or 2.3 million years old (Boivin et al., 2010; Nomade et al., in press, respectively) - the last known record of this genus in Europe. Only pentalophodont upper third molars are observed and anancoidy is very weak. Cement is present in the valleys between the lophs. The M3 of this species is substantially smaller than in $A$. arvernensis arvernensis. Together, these features appear to be the result of the evolution of populations of $A$. arvernensis leading to a reduction in the size of their third molars and the addition of cement to them, among other skull and jaw features mentioned by Boeuf when she proposed $A$. arvernensis chilhiacensis. This subspecies has recently been suggested a synonym of $A$. arvernensis falconeri (Metz-Muller, 2000).

Anancus arvernensis mencalensis. This paper proposes the existence of this chronosubspecies of Anancus for the Early Pleistocene of the Iberian Peninsula.

\section{Anancus in Eastern Europe}

Despite the variability observed in the Anancus samples from the Turolian to the Villafranchian of Eastern Europe, there is no real consensus on the possibility of differentiating more than one species. The Russian species Anancus alexeevae Baigusheva, 1971 does not seem to have been widely recognized in recent papers, although Titov (2008) continues to maintain the subspecies Anancus arvernensis alexeevae for the Villafranchian form from Liventsovska (Russia). A systematic review of this group of Proboscidea is needed for Eastern Europe. The outcome will depend on the completeness of the available fossil remains; the great variability observed for the upper molars may lead to distinctions between morphotypes.

\section{Anancus in Africa}

In Africa, several Anancus species have been differentiated, based on different combinations of cheek tooth features (Sanders, 2011). A. kenyensis is a Late Miocene-Early Pliocene species (7.4-4.3
Ma; Sanders et al., 2010) from eastern and central Africa; it has tetralophodont intermediate molars and upper third molars with five or six lophs and usually unfolded, very thick $(5-7 \mathrm{~mm})$ dental enamel. The crown morphology is simple, with massive lophs and low conelets; anancoidy is weakly expressed. This species evolved into $A$. ultimus, an Early-Mid Pliocene species also from eastern and central Africa. In A. ultimus, the intermediate molars are pentalophodont and upper third molars have six or seven lophs. The enamel is coarsely to finely folded and anancoidy is clear. A. capensis is a Latest Miocene-Early Pliocene species recorded for Langebaanweg (South Africa). It has tetralophodont intermediate molars and upper third molars with six or seven lophs. The enamel shows moderate to strong folding and anancoidy is pronounced. A. petrocchi is a Late Miocene species recorded from As Sahabi (Libya), with pentalophodont intermediate molars and third molars with six lophs; the molar crowns are simple and show weak anancoidy (Sanders, 2007, 2008). Finally, $A$. osiris is a Late Pliocene-Early Pleistocene species from northern Africa (Egypt, Morocco and Algeria). It has tetralophodont intermediate molars, simple M3 crowns with six lophs, no enamel folding, and shows weak anancoidy. Some authors consider $A$. kenyensis and $A$. osiris to be synonymous (Hautier et al., 2009). The similarities between these species were reported by Mackaye (2001). However, other authors of more recent publications continue to give validity to $A$. osiris (Sanders, 2011) as an independent species, a trend that it has been followed in the present work.

\section{DISCUSSION}

The dentition of the aforementioned species of Anancus shows great variability in terms of the number of loph(id)s, a feature mentioned by many other authors (Bergounioux and Crouzel, 1958; Metz-Muller, 1995, 1996; Hautier et al., 2009). The intermediate molars of Anancus are normally tetralophodont, e.g., in $A$. arvernensis, $A$. kenyensis, $A$. capensis and $A$. osiris. In A. petrocchii and $A$. ultimus, however, they are pentalophodont (Sanders, 2008, 2011). One specimen attributed to $A$. sivalensis from the Siwaliks, drawn by Falconer and Cautley (1846), shows also a fifth loph in M2.

The upper third molars of Anancus (Table 3) can have five, six or seven lophs (Kalb and Froehlich, 1995). Thus, in the Eurasian species A. arvernensis, M3 is variable in terms of loph number; specimens with five or six are known. With regard 


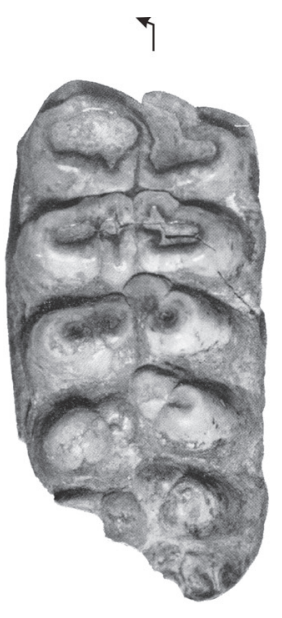

1

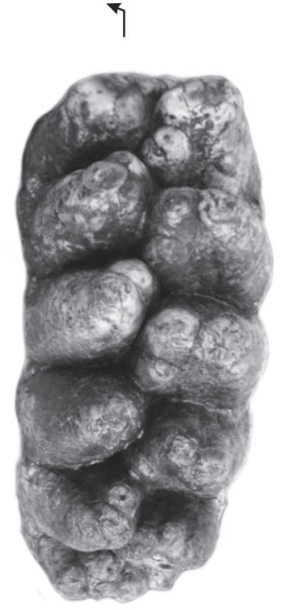

2

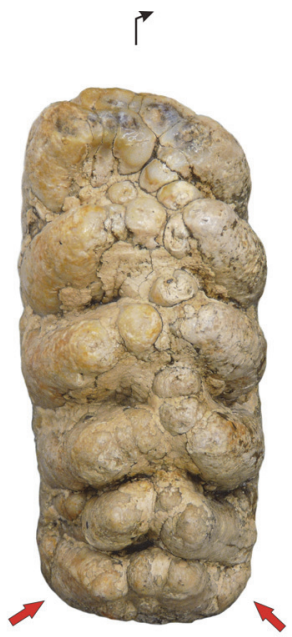

3

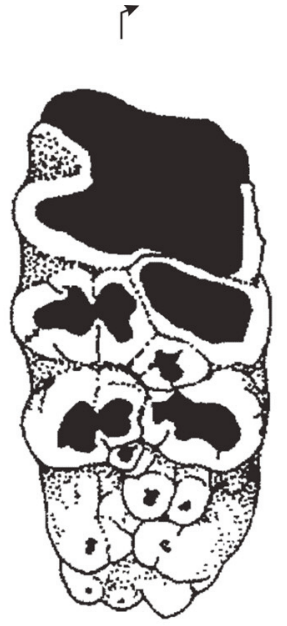

4

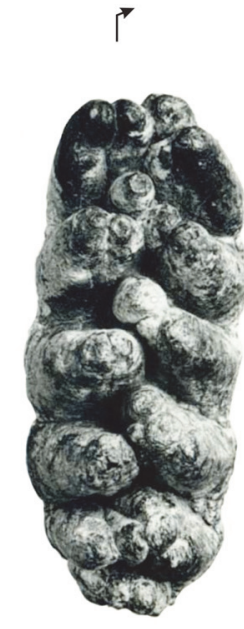

5

FIGURE 6. Comparative occlusal view of the M3 of Anancus arvernensis and Anancus osiris. 1, Anancus sp. cf. Anancus arvernensis turoliensis from Molino de Manuel, Alfacar (from Bergounioux and Crouzel [1958]); 2, Anancus arvernensis arvernensis from Baza-1 (after Ros [2010]); 3, Anancus arvernensis mencalensis from Fonelas SCC-3, described in this paper; 4, Anancus arvernensis chilhiacensis from Chilhac (from Boeuf [1992]); 5, Anancus osiris from Gizeh (from Arambourg [1945]). Red arrows show the rectangular shape of the distal part of the tooth in A. arvernensis mencalensis nov. ssp. Note the resemblance with the shape of the Miocene Anancus from Alfacar. Specimens not to scale.

to the African species, the $\mathrm{M} 3$ of $A$. kenyensis may also have five or six lophs, while those of $A$. ultimus and $A$. capensis have six or seven (Hautier et al., 2009; Sanders, 2011).

The number of lophs is therefore very variable, and although most European specimens have five in their upper third molar (Table 2), the existence of an hexalophodont M3 in the FonelasSCC-3 specimen does not by itself allow any definitive classification to be made. However, it does allow the Metz-Muller's (2000) assertion that there is an absence of hexalophodont upper third molars in MNQ 17 to be rejected.

The upper molars studied from other European sites and attributed to $A$. arvernensis, such as those from Dorkovo (Bulgaria; Metz-Muller, 1995), Baza-1 (Spain; Ros, 2010), Las Higueruelas (Spain; our own data) and Hajnáčka (Slovakia; Lupták, 1997), show a clear anancoid pattern and a pentalophodont M3 (except for some specimens from Dorkovo) with a thick cingulum that runs along the base of the crown-traits not seen in the Fonelas SCC-3 specimen.

Anancoidy-the most important autapomorphic trait included in the diagnosis of the genus -is variable in M3. African forms such as $A$. kenyensis and $A$. osiris barely show an anancoid pattern for their third upper molars (Hautier et al., 2009). It is also very weak in A. petrocchii from As Sahabi (Sand- ers, 2008). Supposedly, as indicated in the specific diagnosis, the molars of $A$. arvernensis are easily recognized by their anancoid structure. Such is the case for all the European specimens that have been attributed to this species (e.g., the Spanish specimens from Las Higueruelas [MGM], Baza-1 [Ros, 2010] or Alcalá del Júcar [Mazo, 1997]), although the lower dental elements generally show more marked anancoidy than the upper ones.

Care must be taken when determining the presence of anancoidy, especially in specimens showing advanced wear. The more worn a tooth is, the more marked anancoidy appears to be. This is due to the fusion (observed by wear) of the pretrite principal tubercles and the pretrite central conules immediately preceding them, and the union of the postrite principal tubercles with the mesoconules. This leads to clearer alternation of the cusps than would be seen in an unworn tooth. This is why the Fonelas SCC-3 seems to show anancoidy in M2, yet there is no real anancoidy in either M2 or M3 (see comparison in Figure 6).

Certain anatomical similarities between $A$. arvernensis and $A$. osiris should be noted (Figure $6)$. These were considered sister taxa by Tassy (1986). A. osiris was described in 1945 by Camile Arambourg based on a complete upper third molar recovered from a site in the deposits of Gizeh near Cairo (Egypt), the age of which is uncertain. Sub- 


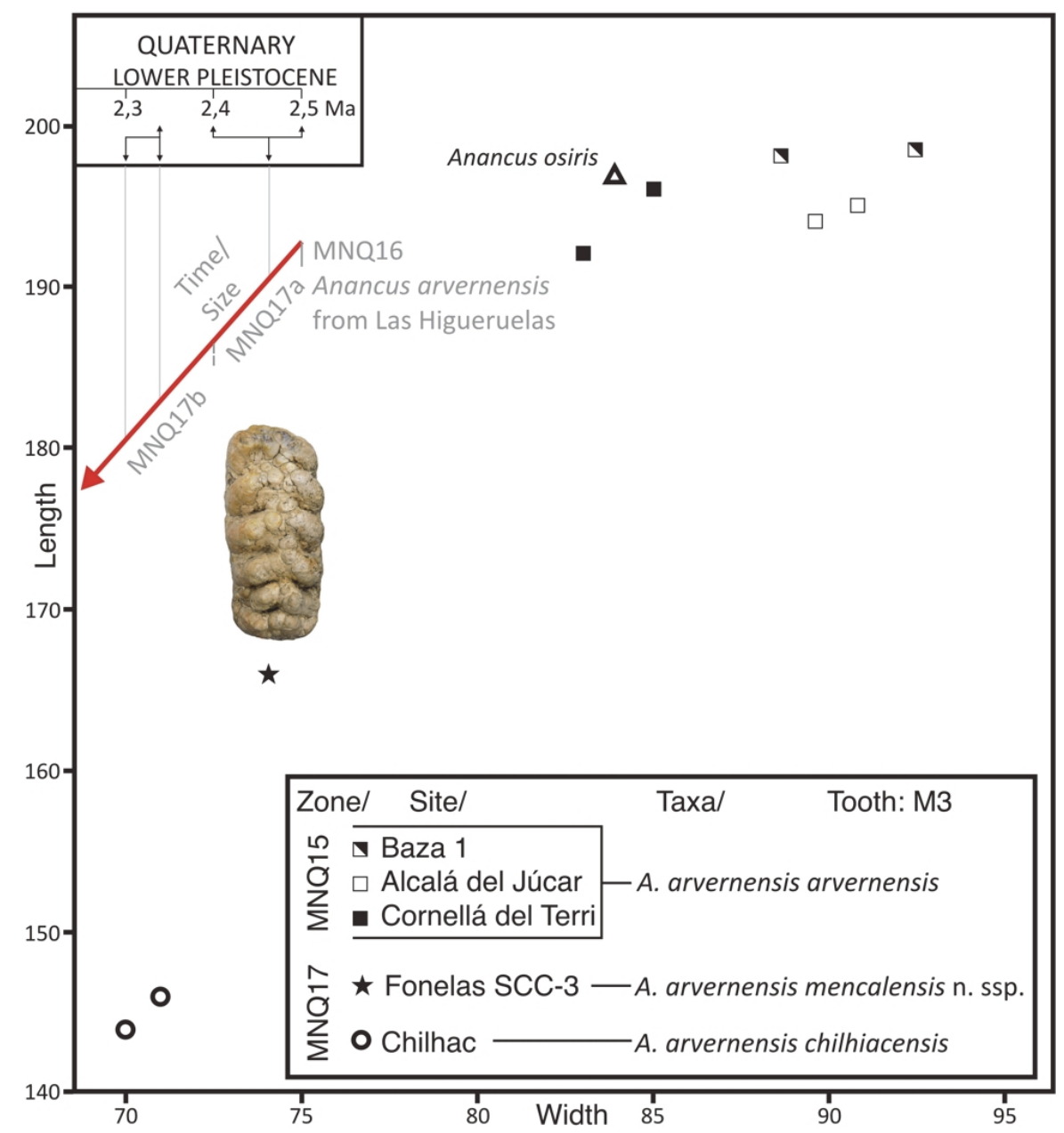

FIGURE 7. Scatter plot of M3 measurements (in $\mathrm{mm}$ ) from Western European Anancus (plus A. osiris from North Africa). Note: no metric data are available in the bibliography for the M3 of $A$. arvernensis from Las Higueruelas (specimens held at the Museo Geominero do not allow the complete visualization of M3).

sequently, $A$. osiris has been cited for other sites of North Africa, such as Ain Boucherit (Algeria; Arambourg, 1970), with an age estimated at $2.32 \mathrm{Ma}$ (Sahnouni et al., 2002), and possibly in Ahl al Oughlam (Morocco), where Anancus sp. cf. A. osiris has been cited with an age of $2.5 \mathrm{Ma}$ (Geraads and Metz-Muller, 1999). In our opinion $A$. osiris might be related to the last forms of $A$. arvernensis (Figure 6, Table 3), but the former is substantially larger (Figure 7). Understanding the phylogenetic relationships between Pleistocene species of Anancus depends on the discovery of new samples that might allow a more in-depth comparison.

Some Spanish specimens in which the anancoid pattern is hardly noticeable have been classified as $A$. arvernensis. Such is the case of the only anancine fossil (an upper third molar) from Molino de Manuel in Alfacar (Granada Basin), described by Bergounioux and Crouzel (1958) and held at the Madrid Natural History Museum (MNCN-12,959). This specimen might be classified as Anancus arvernensis turoliensis, although its revision is beyond the scope of this article. Hence, the absence of anancoidy observed in the Fonelas SCC-3 specimen is shared only by anancines recorded in Turolian deposits, African Anancus and A. arvernensis chilhiacensis from Chilhac (Table 3, Figure 6).

It is important to note that the cement seen in the tooth-valleys of African Anancus has also been reported in $A$. kenyensis and $A$. ultimus (Sanders, 2011). In European specimens, and in late representatives of Anancus such as A. arvernensis chilhiacensis and in the fossil described in the present work, cementum appears in the valleys between 
the cusps. No cement is seen in A. arvernensis arvernensis.

Taking into account the number of lophs in the upper molars, the absence of any basal cingulum or discernable anancoidy, the development of central cusps and a square shape for the distal part of M3, together with the presence of cementum aggregates, the hemimaxilla recovered from Fonelas SCC-3 would appear to be that of a new chronosubspecies. It is here proposed as Anancus arvernensis mencalensis nov. ssp., the most recent Iberian gomphotherid known to date.

A trend towards reduced size in the upper molars (Figure 7) between the Pliocene A. arvernensis arvernensis and the Early Pleistocene subspecies $A$. arvernensis mencalensis and $A$. arvernensis chilhiacensis should be noticed. Such a reduction was previously indicated by Boeuf (1992), who mentions that the jaw size of Anancus arvernensis decreases in size eventually becoming more "brevirostrine." Anancus arvernensis mencalensis nov. ssp. can be understood as a native geographical variation with its own molar characteristic - an adaptative solution to new southern Iberian Quaternary environments as occurs in other Pleistocene Euroasiatic Proboscideans (e.g., Mammuthus; Lister et al., 2005), and probably indicating that an uncommon environment was developed in the Southern part of Iberia that would stimulate local morphologic differentiation.

\section{CONCLUSIONS}

The recognition of Anancus arvernensis mencalensis nov. ssp. in MNQ 17a, an Iberian form of intermediate-size between the typical Pliocene European Anancus arvernensis arvernensis (MNQs 14-15-16) and the French Pleistocene Anancus arvernensis chilhiacensis (MNQ 17b), supports the existence of a temporal cline among these last gomphotheres of southwestern Europe. Anancus arvernensis mencalensis shows important changes in the upper third molar: the lophs face one another reducing anancoidy until its disappearance, the distal part of M3 has a rectangular outline, and cement aggregates are seen in the tooth valleys. The size of the upper third molar is progressively reduced in the lineage $A$. arvernensis arvernensis- $A$. arvernensis mencalensis- $A$. arvernensis chilhiacensis. These changes could have occurred as a response to the aridification that began around 2.5 m.y.a., resulting in changes in the composition of plant communities.

\section{ACKNOWLEDGMENTS}

This study was funded by research projects IGME 2005-009, IGME 2275.11 and by the Consejería de Cultura de la Junta de Andalucía. We express our gratitude to M. Kaiser and J. Roda, the owners of the land where the Fonelas SCC-3 site is located, for allowing us access throughout 2006. M. McDonald, editor of the American Philosophical Society, kindly provided us with useful literature on fossil proboscideans. J. Pascual, of the IGME library, provided us with invaluable help in finding documents. We also thank C. Bonnefon of the Central Library of the Muséum National d'Histoire Naturelle (Paris) for her efforts in providing us with useful literature. Dr. B. Sánchez-Chillón gave us access to comparative materials held at the MNCN, Madrid. We also thank Drs. M.P. Ferretti and $W$. Sanders for sharing with us their extensive knowledge of fossil proboscideans. We would like to thank G.N. Markov for his comments on the preliminary manuscript. A. Burton, E. Díaz and I. Cotarelo provided us with linguistic assistance. Finally, we thank the valuable comments of an anonymous referee which helped to improve the manuscript.

\section{REFERENCES}

Alcalá, L. 1994. Macromamíferos Neógenos de la fosa de Alfambra-Teruel. Instituto de Estudios Turolenses, Museo Nacional de Ciencias Naturales, Teruel.

Alonso, M.A., Hoyos, M., and Alberdi, M.T. 2002. Tafonomía y ambiente sedimentario del yacimiento de Huélago. Estudios Geológicos, 58:11-25.

Arambourg, C. 1945. Anancus osiris, un mastodonte nouveau du Pliocène inférieur d'Egypte. Bulletin de la Societé Géologique de France, 15:479-495.

Arambourg, C. 1970. Les Vertébrés du Pléistocène de l'Afrique du Nord. Archives du Muséum National d'Histoire Naturelle, 10:1-127.

Arribas, A., Garrido, G., Viseras, C., Soria, J.M., Pla, S., Solano, J.G., Garcés, M., Beamud, E., and Carrión, J.S. 2009. A Mammalian Lost World in Southwest Europe during the Late Pliocene. PLoS ONE, 4(9):110. e7127.

Aubekerova, P.A. 1974. A new species of mastodont Anancus kazachstanicus Aubekerova from the location of Esekartkan. Teriologiya, 2: 65-77.

Aymard, A. 1855. Anancus Aymard. Anancus macroplus Aymard. In Dorlhac, M.J, (ed.), Notice géologique sur le cratère de Coupet et sur son gisement de gemmes et d'ossements fossiles. Annales de la Societé d'Agriculture, Sciences, Arts et Commerce du Puy, 19:497-517. 
Baigusheva, V.S. 1971. Fossil Terrestrial Fauna of the Liventsovka Quarry (the Northeastern Azov Region). Materials on Anthropogene Faunas of the USSR, 49:5-28.

Bergonioux, F.M. and Crouzel, F. 1958. Les mastodontes d'Espagne. Estudios Geológicos, 14:223-365.

Boivin, P., Barbet, P., Boeuf, O., Devouard, B., Besson, J.C., Hénot, J.M., Devidal, J.L., Constantin, C., and Charles, L. 2010. Geological setting of the lower Pleistocene fossil deposits of Chilhac (Haute-Loire, France). Quaternary International, 223-224:107-115.

Boeuf, O. 1992. Anancus arvernensis chilhiacensis nov. subsp. (Proboscidea, Mammalia), un mastodonte du Plio-Pléistocène de Haute-Loire, France. Geobios, mém. sp. 14:179-188.

Brookes, J. 1828. A catalogue of the anatomical and zoological museum of Joshua Brookes, part 1. R. Taylor, London.

Cautley, P. 1836. Note on the teeth of the Mastodon a dents etroites of the Siwalik Hills. Journal of the Asiatic Society of Bengal, 5:294-296.

Coppens, Y. 1965. Les Proboscidiens du Tchad, leur contribution à la chronologie du Quaternaire africain. Actas del V Congreso panafricano de Prehistoria y de Estudio del Cuaternario:331-387. Museo Arqueológico de Santa Cruz de Tenerife (Canarias).

Croizet, J.B. and Jobert, A. 1828. Recherches sur les ossements fossiles du département du Puy-deDôme. Clermont-Ferrand, Paris.

Falconer, H. 1857. On the species of mastodon and elephant ocurring in the fossil state in Great Britain Part 1. Mastodon. Quarterly Journal of the geological Society of London, 13:307-360.

Falconer, H. and Cautley, P.T. 1846. Fauna Antiqua Sivalensis, Being the Fossil Zoology of the Sewalik Hills in the North of India. Smith, Elder \& Col. London.

Gaziry, A.W. 1997. Die Mastodonten (Proboscidea, Mammalia) aus Dorn-Dürkheim 1 (Rheinhessen), p. 73-115. In Franzen, J.L. (ed.). Die Säugetiere aus dem Turolium von Dorn-Dürkheim 1 (Rheinhessen, Deutschland). Courier Forschungsinstitut Senckenberg, 197.

Geraads, D. and Metz-Muller, F. 1999. Proboscidea (Mammalia) du Pliocène final d'Ahl al Oughlam (Casablanca, Maroc). Neues Jahrbuch für Geologie und Paläontologie, Monatshefte, 1:52-64.

Gray, J.E. 1821. On the natural arrangement of vertebrose animals. London Medical Repository, 15 (1):296-310.

Guérin C. 1990. Biozones or mammal units? Methods and limits in biochronology, p. 119-130. In Lindsay, E.H., Fahlbusch, V., and Mein, P. (eds.), European Neogene mammal chronology. Plenum.

Guérin, C. 2004. Les Proboscidiens (Mammalia) du gisement villafranchien moyen de Saint Vallier (Drôme, France). Geobios, 37, Supp. 1:306-317.
Hautier, L., Mackaye, H.T., Lihoreau, F., Tassy, P., Vignaud, P., and Brunet, M. 2009. New material of Anancus kenyensis (Proboscidea, mammalia) from TorosMenalla (Late Miocene, Chad): Contribution to the systematics of African anancines. Journal of African Earth Sciences, 53:171-176.

Hay, O.P. 1922. Further observations of some extinct elephants. Proceedings of the Biological Society of Washington, 35:97-101.

Hays, I. 1834. Descriptions of the specimens of interior maxillary bones of Mastodons in the Cabinet of the American Philosophical Society, with remarks on the genus Tetracaulodon. Transactions of the American Philosophical Society, N.S., IV:317-339.

Hopwood, A.T. 1935. Fossil Proboscidea from China. Paleontologia Sinica, C9:1-108.

Illiger, C.D. 1811. Prodromus systematis mammalium et avium additis terminis zoographicis uttriusque classis. Salfeld, Berlin, $301 \mathrm{pp}$.

Kalb, J.E. and Froehlich, D.J. 1995. Interrelationships of Late Neogene Elephantoids: new evidence from the Middle Awash Valley, Afar, Ethiopia. Geobios, 28:727-736.

Lister, A.M., Sher, A.V., van Essen, H., and Wei, G. 2005. The pattern and process of mammoth evolution in Eurasia. Quaternary International, 126-128:49-64.

Lourens, L., Hilgen, F.J., Shackleton, N.J., Laskar, J., and Wilson, D. 2004. The Neogene Period, p. 409440. In Gradstein, F.M., Ogg, J.G., and Smith, A.G. (eds.), A Geological Time Scale 2004. Cambridge University Press.

Lupták, P. 1997. Upper jaw fragment of the Anancus arvernensis (Croizet \& Jobert 1828) (Mastodontidae, Proboscidea, Mammalia) from the Villafranchian of Hajnáčka, Slovakia. Geologica Carpathica, 48 (5):341-343.

Maclnnes, D.G. 1942. Miocene and post-Miocene Proboscidea from East Africa. Transactions of the Zoological Society of London, 25:33-106.

Mackaye, H.T. 2001. Les proboscidiens du Mio-Pliocène du Tchad : Biodiversité, Biochronologie, Paléoécologie et Paléobiogéographie. Unpublished PhD Thesis, University of Poitiers.

Mazo, A.V. 1997. El yacimiento Rusciniense de Alcalá del Júcar (Albacete). Taxonomía y bioestratigrafía. Estudios Geológicos, 53:275-286.

Mazo, A.V. and van der Made, J. 2012. Iberian mastodonts: Geographic and stratigraphic distribution. Quaternary International, 255:239-256.

Mazo, A.V., Alberdi, M.T., and Bone, E. 1980. Le gisement à Anancus arvernensis d'Alcolea de Calatrava (Ciudad Real) dans la Ruscinien (Pliocène) de la Mesete espagnole. Bulletin de la Société Belge de Géologie, 89 (3):145-178.

Mein, P. 1990. Updating of MN zones, p.73-90. In Lindsay, E.H., Fahlbusch, V., and Mein, P. (eds.), European Neogene mammal chronology. Plenum. 
Metz-Muller, F. 1995. Mise en évidence d'une variation intra-spécifique des caractères dentaires chez Anancus arvernensis (Proboscidea, Mammalia) du gisement de Dorkovo (Pliocène ancien de Bulgarie, Biozone MN14). Geobios, 28 (6):737-743.

Metz-Muller, F. 1996. A mandible of Anancus arvernensis (Proboscidea, Mammalia, Pliocene) with pentalophodont M2's - significance of the pentalophodont grade in Anancus. Neues Jahrbuch für Geologie und Paläontologie, Monatshefte, 12:709-726.

Metz-Muller, F. 2000. La population d'Anancus arvernensis (Proboscidea, Mammalia) du Pliocène de Dorkovo (Bulgarie); étude des modalités évolutives d'Anancus arvernensis et phylogénie du genre Anancus. Unpublished PhD Thesis, Muséum National d'Histoire Naturelle, Paris.

Nesti, F. 1825. Sulla nuova specie di elefante fossile del Valdarno all'illustrisimo Sig. Dott. Prof. Ottaviano Targioni Torzzetti (Lettera sopra alcune ossa fossili del Valdarno non per anco descritte). Nuovo Giornale dei Letterati II, 24:195-216.

Nomade, S., Pastre, J.F., Guillou, H., Faure, M., Guérin, C., Delson, E., Debard, E., Voinchet, P., and Messager, E. In press. ${ }^{40} \mathrm{Ar} /{ }^{39} \mathrm{Ar}$ constraints on some French landmark Late Pliocene to Early Pleistocene large mammalian paleofauna: paleoenvironmental and paleoecological implications. Quaternary Geochronology. doi: 10.1016/j.quageo.2012.12.006.

Osborn, M.F. 1926. Additional new genera and species of the mastodontoid Proboscidea. American Museum Novitates, 238:1-16.

Palombo, M.R. and Valli, A.M.F. 2003. Remarks on the biochronology of mammalian faunal complexes from the Pliocene to the Middle Pleistocene in France. Geologica Romana, 37:145-163.

Pla-Pueyo, S., Viseras, C., Soria, J.M., Tent-Manclús, J.E., and Arribas, A. 2011. A stratigraphic framework for the Pliocene-Pleistocene continental sediments of the Guadix Basin (Betic Cordillera, S. Spain ). Quaternary International, 243(1):16-32.

Ros, S. 2010. Los Proboscídeos del Plio-Pleistoceno de las Cuencas de Guadix-Baza y Granada. Unpublished PhD Thesis, Universidad de Granada.
Sahnouni, M., Hadjouis, D., Van der Made, J., Derradji, A., Canals, A., Medig, M., Belahrech, H., Harichane, Z., and Rabhi, M. 2002. Further research at the Oldowan site of Aïn Hanech, north-eastern Algeria. Journal of Human Evolution, 43:925-937.

Sanders, W.J. 2007. Taxonomic review of fossil Proboscidea (Mammalia) from Langebaanweg, South Africa. Transactions of the Royal Society of South Africa, 62 (1):1-16.

Sanders, W.J. 2008. Review of fossil Proboscidea from the Late Miocene-Early Pliocene site of As Sahabi, Libya. Garyounis Scientific Bulletin, Special Issue, 5:241-256.

Sanders, W.J. 2011. Proboscidea, p. 233-262. In Harrison, T. (ed.), Paleontology and Geology of Laetoli: Human Evolution in Context. Volume 2: Fossil Hominins and the Associated Fauna. Springer Science+Business Media.

Sanders, W.J., Gheerbrant, E., Harris, J.M., Saegusa, H., and Delmer, C. 2010. Proboscidea, p. 161-251. In Werdelin, L. and Sanders, W.J. (eds.), Cenozoic Mammals of Africa. University of California Press.

Tassy, P. 1986. Nouveaux Elephantoidea (Mammalia) dans le Miocène du Kenya. Cahiers de Paléontologie, CNRS.

Teilhard de Chardin, P. and Trassaert, M. 1937. The Proboscideans of southeastern Shansi. Palaeontologia Sinica, C13:1-58.

Titov, V. 2008. Late Pliocene large mammals from Northeastern Sea Azov Region. PhD Thesis, Rostov-onDon: SSC RAS Publishing.

Villalta, J.F. 1952. Contribución al conocimiento de la fauna de mamíferos fósiles del Plioceno de Villarroya (Logroño). Boletín del Instituto Geológico y Minero de España, 64.

Viret, J. 1954. Le loess à bancs durcis de Saint-Vallier (Drôme) et sa faune de mammifères villafranchiens. Nouvelles Archives du Museum d'Histoire Naturelle de Lyon, 4.

Viseras, C. 1991. Estratigrafía y sedimentología del relleno aluvial de la Cuenca de Guadix (Cordilleras Béticas). Unpublished PhD Thesis, Universidad de Granada. 